\title{
GAIT DISORDERS IN PATIENTS AFTER POLYTRAUMA
}

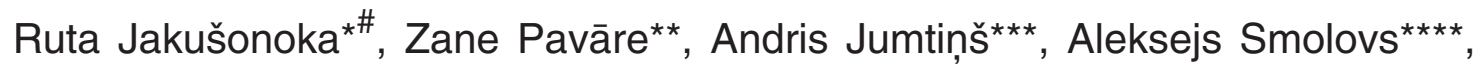 \\ and Tatjana Anan,jeva**** \\ * Department of Orthopaedic Surgery, Rīga Stradiṇš University, Duntes iela 22, Rīga, LV-1005, LATVIA; \\ ruta.jakusonoka@nmpd.gov.lv \\ ** Rehabilitation Research Laboratory, Rīga Stradiṇš University, Anniṇmuižas bulv. 26, Rīga, LV-1067, LATVIA; \\ National Rehabilitation Centre "Vaivari", Asaru prospekts 61, Jūrmala, LV-2008, LATVIA; \\ gaitazp@inbox.lv \\ *** Rīga Stradiṇš University, Dzirciema iela 16, Rīga, LV-1005, LATVIA; \\ andris.jumtins@rsu.Iv \\ ${ }^{\star * \star \star}$ National Rehabilitation Centre "Vaivari", Asaru prospekts 61, Jūrmala, LV-2008, LATVIA; \\ alekseysmolov@gmail.com, tatjana.ananjeva@rsu.lv \\ \# Corresponding author \\ Communicated by Dainis Krieviṇš
}

\begin{abstract}
Evaluation of the gait of patients after polytrauma is important, as it indicates the ability of patients to the previous activities and work. The aim of our study was to evaluate the gait of patients with lower limb injuries in the medium-term after polytrauma. Three-dimensional instrumental gait analysis was performed in 26 polytrauma patients (16 women and 10 men; mean age 38.6 years), 14 to 41 months after the trauma. Spatio-temporal parameters, motions in pelvis and lower extremities joints in sagittal plane and vertical load ground reaction force were analysed. Gait parameters in polytrauma patients were compared with a healthy control group. Polytrauma patients in the injured side had decreased step length, cadence, hip extension, maximum knee flexion, vertical load ground reaction force, and increased stance time and pelvic anterior tilt; in the uninjured side they had decreased step length, cadence, maximum knee flexion, vertical load ground reaction force and increased stance time $(\mathrm{p}<0.05)$. The use of the three-dimensional instrumental gait analysis in the evaluation of polytrauma patients with lower limb injuries consequences makes it possible to identify the gait disorders not only in the injured, but also in the uninjured side.
\end{abstract}

Key words: injuries, gait cycle, gait analysis.

\section{INTRODUCTION}

One of important problems in patient rehabilitation is identification of gait disorders (GD) in patients with lower limb injuries after polytrauma. Polytrauma is defined as a syndrome of multiple injuries exceeding a defined severity (Injury Severity Score (ISS) $\geq 17$ ) with sequential systemic reactions that may lead to dysfunction or failure of remote organs and vital systems, which have not themselves been directly injured (Trentz, 2007). Injury severity affects final functional outcome. Polytrauma patients who have associated orthopaedic injuries face greater challenges regarding functional recovery. Prompt diagnosis and treatment of functional abnormalities of patients after polytrauma is very important (Tran and Thordarson, 2002). The teams who treat polytrauma patients in hospitals receive limited information about the GD after multiple traumatic injuries (Pape et al., 2006). Fast evaluation can improve success in the correction of lower limb functional abnormalities (Pfeifer and Pape, 2011). However, using only clinical methods in the evaluation of patients with lower extremity injuries after polytrauma does not give data about motions of lower extremities during gait and causes of gait pathology.

Three-dimensional instrumental gait analysis (IGA) is an instrumental examination method, which is used to acquire and convert images of gait into quantitative data describing the motions of each body segment (Perry and Burnfield, 2010). The aim of the study was to use the method to evaluate the gait in follow-up of patients, who suffered severe lower limb injuries, in the medium-term after polytrauma.

\section{MATERIALS AND METHODS}

A retrospective study of 154 polytrauma patients, treated after severe musculoskeletal injuries in two Rīga Hospitals (Trauma and Orthopaedic Department, Clinic „Gail̨ezers”, Rìga Eastern Clinical University Hospital; Hospital of Traumatology and Orthopaedics) over the period 2008-2010, was performed. The ISS and New Injury Severity Score 
(NISS) values were calculated for all of these patients. NISS values were used to evaluate the severity of polytrauma injuries, as ISS does not give objective information about the amount of work and resources required if the patient has serious multiple injuries in one of the ISS anatomic regions, particularly regarding orthopaedic injuries (Stevenson, 2001). The lower extremity injuries in our study were defined as pelvic and acetabular fractures, hip dislocation, femoral fracture, tibial fracture and complex foot injury.

Patients aged 18-60 were included in the retrospective study group for IGA study if they had at least one severe lower extremity injury. Excluded were patients with bilateral lower limbs injuries, spine trauma with neurological injury, lower limb amputation or documented psychiatric disease. The patients who moved to other country, did not respond to phone calls and the invitation letter, had lower limb trauma after polytrauma or inability to walk barefoot a distance of 7-8 meters 6-10 times, also were excluded from the study.

Thus the study was conducted on 26 polytrauma patients with lower extremity injuries in the Rehabilitation Research Laboratory of Rìga Stradiňš University, National Rehabilitation Centre "Vaivari", 14 to 41 months (mean 22 months) after polytrauma. Patient complaints, clinical examination, radiological examination and IGA were included in the evaluation. Patients were asked to evaluate their leg pain according to the following variables: „no pain”, „moderate pain” or „severe pain”. The time of fracture healing was determined. We used anteroposterior and lateral radiograph views of the lower limbs and anteroposterior, inlet and outlet views of the pelvis to assess the fracture healing. IGA of 26 healthy volunteers aged 18-65 (17 women and 9 men; age range 19-65, mean age 35.9 years) without any musculoskeletal disorders for the control group was performed.

IGA was performed using six infrared light ProReflex MCU $(240 \mathrm{~Hz})$ digital cameras (Qualisys Medical, Sweden), a force plate (Advanced Mechanical Technology, Inc., Watertown, USA) and Visual 3-D software, developed in the National Health Institute, USA (C-motion, Inc, USA). Subjective and objective evaluation of the patients' musculoskeletal system was performed before IGA. Light, spherical reflective markers $(19 \mathrm{~mm})$ were attached to the skin to identify bony landmarks (the first sacral vertebra, both anterior superior iliac spinae, lateral surfaces of femur and shin, the heads of first and fifth metatarsal bones and the calcaneal bones). Patients had to walk barefoot a distance of 7-8 meters, 6-10 times at a self-selected speed. The spatial coordinates of the markers' were registered during recording of gait and motion trajectories of the markers were calculated. The patient had to put one foot on the force plate on the floor that registered ground reaction force (GRF). Visual gait recording was obtained with two digital video cameras. The findings were processed with data processing programmes in the form of diagrams and numbers. The motion parameters of the pelvis and lower extremity joints during the gait were shown in the diagrams. The spatio-temporal parameters of the gait cycle were registered in the form of numbers (Ananjeva et al., 2010).

From the gait cycle, kinematic variables included were motions in pelvis and lower extremities joints in sagittal plane. Vertical load GRF was used as a kinetic variables. The definitions of gait cycle kinematic and kinetic variables used in our study are displayed in Table 1 .

Table 1

DEFINITIONS OF GAIT CYCLE KINEMATIC AND KINETIC VARIABLES USED IN THE STUDY

\begin{tabular}{|c|c|}
\hline Variables & Definitions \\
\hline \multicolumn{2}{|r|}{ Pelvis ROM in sagittal plane } \\
\hline Anterior tilt & Maximum anterior pelvic tilt during terminal stance \\
\hline \multicolumn{2}{|r|}{ Hip ROM in sagittal plane } \\
\hline Maximum flexion & Maximum hip flexion during initial contact \\
\hline Minimum flexion & Minimum hip flexion during terminal stance \\
\hline \multicolumn{2}{|r|}{ Knee ROM in sagittal plane } \\
\hline Maximum flexion & Maximum knee flexion during mid swing \\
\hline Minimum flexion & Minimum knee flexion during terminal stance \\
\hline \multicolumn{2}{|r|}{ Ankle ROM in sagittal plane } \\
\hline Maximum flexion & Maximum plantar flexion during pre-swing \\
\hline Minimum flexion & Minimum plantar flexion during mid stance \\
\hline $\begin{array}{l}\text { Maximum exten- } \\
\text { sion }\end{array}$ & Maximum dorsal flexion during mid stance \\
\hline \multicolumn{2}{|r|}{ Vertical load GRF } \\
\hline GRF V1 & Maximum vertical load GRF during loading responce \\
\hline GRF V2 & Maximum vertical load GRF during terminal stance \\
\hline
\end{tabular}

ROM: range of motion $\left(^{\circ}\right)$; GRF: ground reaction force (body weight)

Gait cycle spatio-temporal parameters, motions in pelvis and lower extremity joints in sagittal plane and vertical load GRF of patients in the injured and uninjured side were determined. Gait parameters of the injured and uninjured side in the polytrauma patients were compared with the lower extremity gait parameters of the control group. In order to evaluate if articular fractures influence gait parameters, we selected two patient groups: patient group with articular lower extremities fractures and a patient group with extraarticular lower extremities fractures.

Variables were expressed as means \pm standard deviations (SD) and were compared using the Independent Samples T test or Mann-Whitney test for two independent samples, as needed. Analysis was performed with the SPSS programme version 20.0. A $p$ value $<0.05$ was considered statistically significant.

\section{RESULTS}

The study was conducted on 26 (16 women and 10 men, age range $23-59$, mean age 38.6 years; NISS $17-48$, mean NISS value 25.9) of 154 retrospective study polytrauma patients. Sixty-nine patients were excluded from the study: 24 
patients did not have lower limb injuries, eight patients had bilateral lower limb injuries, 27 patients did not correspond to the age criteria, five patients had lower limb amputation, and five patients had documented psychiatric disease. Thus, eighty-five patients were invited to undergo the outcome evaluation according to their residences from the hospital case-records of the patients. Of them, excluded were nine patients had moved to other country, 27 patients did not respond to phone calls and letter, 13 patients refused to undergo the IGA, one patient had fracture of proximal segment of tibia six months before recruitment, three patients could not walk the mentioned distance.

Types of injuries. Twenty-six polytrauma patients included in our study had 72 lower extremities injuries (Table 2).

Table 2

INJURY PATTERN OF LOWER EXTREMITIES IN POLYTRAUMA PATIENTS

\begin{tabular}{|c|c|}
\hline INJURY PATTERN & $\mathrm{n}$ \\
\hline Pelvic ring fracture (AO classification) & 11 \\
\hline Type A & 4 \\
\hline Type B & 7 \\
\hline Acetabular fracture (Judet \& Letournel classification) & 3 \\
\hline Type B & 2 \\
\hline Type C & 1 \\
\hline Femoral fractures (AO classification) & 16 \\
\hline Proximal segment: 1 type A; 2 type B & 3 \\
\hline Diaphysis: 8 type $\mathrm{A} ; 2$ type $\mathrm{B} ; 1$ type $\mathrm{C}$ & 11 \\
\hline Distal segment: 1 type $\mathrm{B} ; 1$ type $\mathrm{C}$ & 2 \\
\hline Tibial fractures (AO classification) & 9 \\
\hline Proximal segment: 1 type B & 1 \\
\hline Diaphysis: 1 type $A ; 2$ type $B ; 2$ type $C$ & 5 \\
\hline Distal segment: 1 type A; 2 type C & 3 \\
\hline Fibular fractures (AO classification) & 9 \\
\hline Proximal segment: 1 type A; 1 type $\mathrm{C}$ & 2 \\
\hline Diaphysis: 1 type B & 1 \\
\hline Distal segment: 2 type A; 3 type B & 6 \\
\hline Patellar fractures & 4 \\
\hline Ankle dislocations & 2 \\
\hline Talar articular fractures & 3 \\
\hline Calcaneum articular fractures & 2 \\
\hline Navicular fractures & 1 \\
\hline Cuboid fractures & 1 \\
\hline Cuneiform fracture & 2 \\
\hline Metatarsal fractures & 6 \\
\hline Lisfranc joint partial displacement & 1 \\
\hline Great toe proximal phalangx fracture & 1 \\
\hline Great toe amputation & 1 \\
\hline
\end{tabular}

Sixteen patients had articular fractures and ten patients had extra-articular fractures. There were three open femoral shaft fractures, one open fracture of the distal segment of the femur, one open fracture of the tibial shaft, and two open ankle dislocations. Associated lower extremity injuries included two sciatic nerve injuries and one deep peroneal nerve injury. Seventeen patients had more than one lower extremity injury. Other associated injuries included 11 upper limb injuries, 8 spine injuries, 10 head injuries, $5 \mathrm{ab}$ dominal injuries and 11 chest injuries.

Fracture healing. Twenty-three patients had delayed fracture healing. One patient had non-union of femoral fracture and re-operation, and IGA was performed after fracture healing. Two patients had fracture healing in the average healing times. Seventeen patients took a rehabilitation course after hospital discharge. Six patients had no pain, 14 patients had moderate pain, and six patients had severe pain during evaluation.

Analysis of the spatio-temporal parameters of gait cycle. The gait cycle spatio-temporal parameters of the polytrauma patient group in the injured and uninjured side differed from those of the same side of the control group. In the injured side step length was $0.53 \pm 0.10 \mathrm{~m}$ vs. $0.64 \pm 0.61 \mathrm{~m}, p=0$; stance time $63.50 \pm 3.70 \%$ vs. $61.80 \pm 1.70 \%$, of gait cycle, $p=0.02 ;$ and cadence $93.00 \pm 16.71$ steps $/ \mathrm{min}$ vs. $112.00 \pm$ $8.44 \mathrm{steps} / \mathrm{min}, p=0$, respectively. In the uninjured side step length was $0.55 \pm 0.12 \mathrm{~m}$ vs. $0.65 \pm 0.06 \mathrm{~m}, p=0.001$; stance time $66.70 \pm 5.64 \%$ vs. $61.81 \pm 1.26 \%$ of gait cycle, $p=0$; and cadence $94.00 \pm 14.25$ steps/min vs. $113.00 \pm$ 9.86 steps/min, $p=0$, respectively. The polytrauma patients had decreased walking speed $0.87 \pm 0.27 \mathrm{~m} / \mathrm{s}$ vs. $1.21 \pm$ $0.16 \mathrm{~m} / \mathrm{s}, p=0$ in comparison with the control group.

Analysis of motions in the sagittal plane. The comparison of IGA sagittal plane motion in the pelvis, hip, knee and ankle joints of the injured side in the polytrauma patient and control groups showed that polytrauma patients had increased pelvic anterior tilt, decreased hip extension and knee maximum flexion $(p<0.05)$ (Table 3$)$.

Table 4 summarizes IGA sagittal plane motion results in the pelvis, hip, knee and ankle joints of the uninjured side in the polytrauma patient and control groups.

The results showed significantly decreased knee maximum flexion $(p<0.05)$ in the polytrauma patient group in the uninjured side (Fig. 1).

Comparison of the hip and ankle joint minimum flexion in the injured side and hip minimum flexion in the uninjured side of polytrauma patients with those of the control group was not possible, as six patients had hip minimum flexion and two patients had ankle minimum flexion in the injured side, five patients had hip minimum flexion in the uninjured side, but all persons of the control group had full range of motion in these joints.

While three polytrauma patients had increased pelvic posterior tilt in both the injured and uninjured side, one patient had increased pelvic posterior tilt only in the injured side. Two polytrauma patients did not have ankle extension in the injured side because of ankle joint flexion contracture. 
PELVIC, HIP, KNEE AND ANKLE JOINTS SAGITTAL PLANE MOTIONS IN THE INJURED LOWER EXTREMITY OF POLYTRAUMA PATIENT AND HEALTHY CONTROL GROUPS DURING GAIT CYCLE

\begin{tabular}{|c|c|c|c|c|c|}
\hline \multirow[t]{2}{*}{ PARAMETER } & \multicolumn{2}{|c|}{ Polytrauma group $(n=26)$} & \multicolumn{2}{|c|}{ Control group $(n=26)$} & \multirow[t]{2}{*}{$p$ value } \\
\hline & mean $\pm \mathrm{SD}\left({ }^{\circ}\right)$ & $\mathrm{n}$ & mean $\pm \mathrm{SD}\left({ }^{\circ}\right)$ & $\mathrm{n}$ & \\
\hline Pelvic anterior tilt & $9.80 \pm 8.34$ & $\mathrm{n}=22$ & $5.52 \pm 3.93$ & $\mathrm{n}=15$ & $0.009 *$ \\
\hline Hip flexion, max & $24.08 \pm 10.04$ & $\mathrm{n}=26$ & $24.54 \pm 6.84$ & $\mathrm{n}=26$ & $0.387^{*}$ \\
\hline Hip flexion, min & $6.66 \pm 4.50$ & $\mathrm{n}=6$ & - & - & - \\
\hline Hip extension & $8.90 \pm 6.68$ & $\mathrm{n}=20$ & $15.15 \pm 9.27$ & $\mathrm{n}=26$ & $0.025^{* *}$ \\
\hline Knee flexion, $\max$ & $58.26 \pm 8.38$ & $\mathrm{n}=26$ & $61.76 \pm 4.96$ & $\mathrm{n}=26$ & $0.040^{*}$ \\
\hline Knee flexion, min & $8.95 \pm 5.18$ & $\mathrm{n}=22$ & $7.15 \pm 3.63$ & $\mathrm{n}=20$ & $0.300^{* *}$ \\
\hline Knee extension & $4.25 \pm 3.09$ & $\mathrm{n}=4$ & $2.50 \pm 3.01$ & $\mathrm{n}=6$ & $0.377 * *$ \\
\hline Ankle flexion, max & $16.48 \pm 7.80$ & $\mathrm{n}=25$ & $17.85 \pm 6.03$ & $\mathrm{n}=26$ & $0.396^{* *}$ \\
\hline Ankle flexion, min & $3.50 \pm 2.12$ & $\mathrm{n}=2$ & - & - & - \\
\hline Ankle extension & $8.58 \pm 3.20$ & $\mathrm{n}=24$ & $9.04 \pm 2.25$ & $\mathrm{n}=26$ & $0.561 *$ \\
\hline
\end{tabular}

SD: standard deviation; n, number of patients; * Independent Samples T test; ** Mann-Whitney test for 2 independent samples; - absence of the parameter in the control group and $p$ value

Table 4

PELVIC, HIP, KNEE AND ANKLE JOINTS SAGITTAL PLANE MOTIONS IN THE UNINJURED LOWER EXTREMITY OF POLYTRAUMA PATIENT AND HEALTHY CONTROL GROUPS DURING GAIT CYCLE

\begin{tabular}{|c|c|c|c|c|c|}
\hline \multirow[t]{2}{*}{ PARAMETER } & \multicolumn{2}{|c|}{ Polytrauma group $(n=26)$} & \multicolumn{2}{|c|}{ Control group $(n=26)$} & \multirow[t]{2}{*}{$p$ value } \\
\hline & mean $\pm \mathrm{SD}\left({ }^{\circ}\right)$ & $\mathrm{n}$ & mean $\pm \mathrm{SD}\left({ }^{\circ}\right)$ & $\mathrm{n}$ & \\
\hline Pelvic anterior tilt & $8.22 \pm 5.88$ & $\mathrm{n}=23$ & $6.07 \pm 4.39$ & $\mathrm{n}=15$ & $0.280 * *$ \\
\hline Hip flexion, max & $27.50 \pm 11.90$ & $\mathrm{n}=26$ & $25.62 \pm 6.80$ & $\mathrm{n}=26$ & $0.487 *$ \\
\hline Hip flexion, min & $8.80 \pm 6.30$ & $\mathrm{n}=5$ & - & - & - \\
\hline Hip extension & $9.24 \pm 10.15$ & $\mathrm{n}=21$ & $12.27 \pm 7.77$ & $\mathrm{n}=26$ & $0.079 * *$ \\
\hline Knee flexion, max & $54.77 \pm 12.88$ & $\mathrm{n}=26$ & $60.85 \pm 3.65$ & $\mathrm{n}=26$ & $0.025^{*}$ \\
\hline Knee flexion, min & $9.55 \pm 4.50$ & $\mathrm{n}=19$ & $7.95 \pm 3.89$ & $\mathrm{n}=21$ & $0.106^{* *}$ \\
\hline Knee extension & $3.57 \pm 3.73$ & $\mathrm{n}=7$ & $2.40 \pm 2.51$ & $\mathrm{n}=5$ & $0.677 * *$ \\
\hline Ankle flexion, $\max$ & $16.23 \pm 6.40$ & $\mathrm{n}=26$ & $17.04 \pm 5.87$ & $\mathrm{n}=26$ & $0.638^{*}$ \\
\hline Ankle extension & $10.12 \pm 4.10$ & $\mathrm{n}=26$ & $10.15 \pm 1.93$ & $\mathrm{n}=26$ & $0.953 *$ \\
\hline
\end{tabular}

SD: standard deviation; n: number of patients; *: Independent Samples T test; **: Mann-Whitney test for 2 independent samples; -: absence of the parameter in the control group and $p$ value

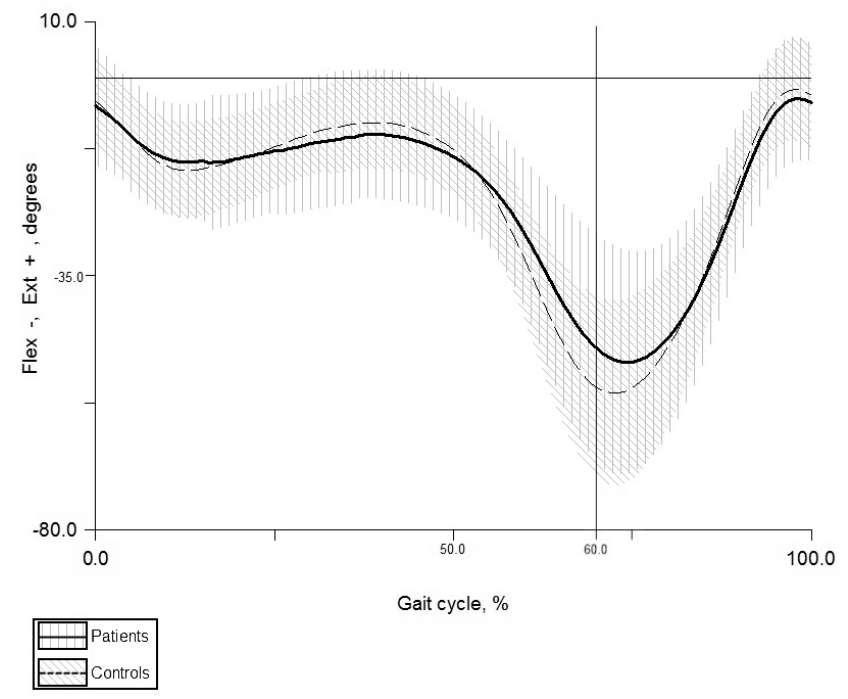

Fig. 1. Knee joint motions in sagittal plane in the uninjured lower extremity of polytrauma patient and healthy control groups.
Analysis of vertical load ground reaction force. In the injured side of patient and the control group, vertical load GRF during loading response was $0.95 \pm 0.06$ body weight v.s. $1.05 \pm 0.08$ body weight, $p=0$ and during terminal stance $1.02 \pm 0.08$ body weight vs. $1.14 \pm 0.08$ body weight, $p=0$, respectively. In the uninjured side vertical load GRF during loading response was $0.97 \pm 0.06$ body weight vs. $1.05 \pm 0.09$ body weight, $p=0.001$ and during terminal stance $1.02 \pm 0.19$ body weight vs. $1.13 \pm 0.08$ body weight, $p=0.014$, respectively. Figure 2 shows significantly decreased vertical load GRF during loading response and terminal stance in the uninjured side of the patient group $(p<0.05)$.

Patients with articular fractures in the injured side had different following sagittal plane motion parameters than in those with extra-articular fractures: hip flexion $23.13 \pm$ $11.39^{\circ}(\mathrm{n}=16)$ vs. $25.30 \pm 7.57^{\circ}(\mathrm{n}=10)$; hip extension $8.77 \pm 6.52^{\circ}(\mathrm{n}=13)$, vs. $10.00 \pm 6.58^{\circ}(\mathrm{n}=7)$; knee mini- 


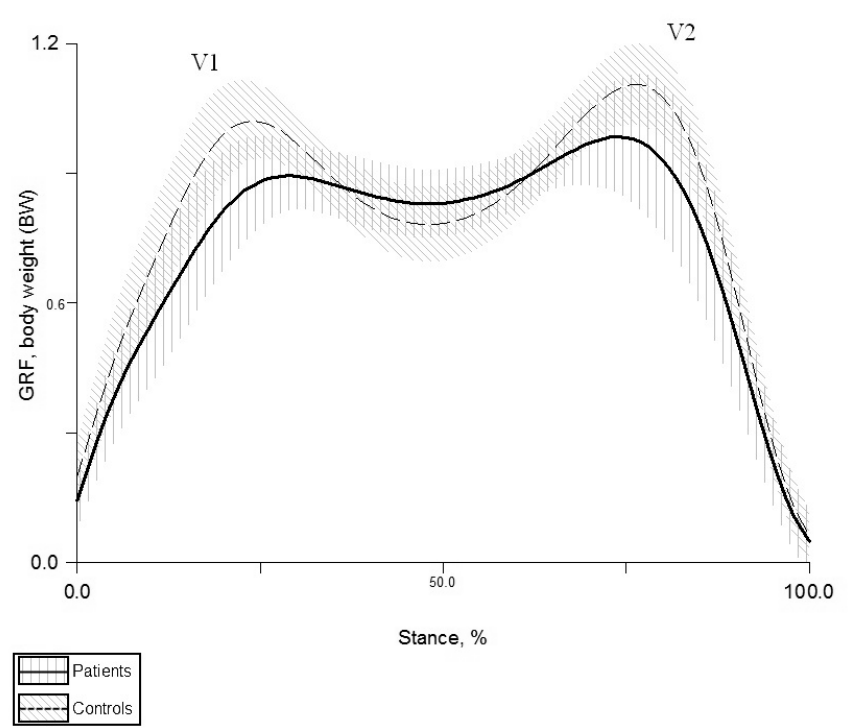

Fig. 2. Vertical load ground reaction force in the uninjured lower extremity of polytrauma patient and healthy control groups.

mum flexion $9.31 \pm 5.76^{\circ}(\mathrm{n}=13)$ vs. $7.56 \pm 4.72^{\circ}(\mathrm{n}=9)$; and ankle maximum flexion $15.40 \pm 7.15^{\circ}(\mathrm{n}=15)$ vs. $16.80 \pm 10.04^{\circ}(\mathrm{n}=10)$, respectively, but the sample sizes were too small to achieve statistical significance. Five patients with articular fractures and one patient with extraarticular fractures did not exhibit hip extension during terminal stance; and one patient with articular fractures did not have ankle maximum flexion during pre-swing of gait cycle.

\section{DISCUSSION}

The evaluation of patient gait with lower limb injuries after polytrauma is important as it allows to improve rehabilitation programmes aimed at quicker return to previous activities and work. According to the literature, patients with consequences of severe lower extremities trauma have gait asymmetry and decreased walking speed, which were diagnosed using visual gait monitoring and stopwatch (Archer $e t$ al., 2006). We evaluated patients using IGA, which allows to acquire quantitative data describing the motions of lower extremities during the gait.

Many spatio-temporal parameters in both the injured and uninjured side in our study were significantly lower than those in the control group. The sagittal plane pelvic motions variables used in the injured side are of the same kind as in a previous study (Kubota et al., 2012), which showed significant pelvic anterior tilt in patients after acetabular fractures. Most of the patients in our study had increased pelvic anterior tilt in both sides, which showed inability to extend the hip joints during the stance phase of the gait cycle because of contracture or a shorter leg in the injured side. In our study, polytrauma patients had also decreased knee maximum flexion in both injured and uninjured sides and decreased hip extension only in the injured side. Although the changed arch of motion of the knee joint during gait cycle in patients was small, it resulted in significant changes of foot and body location. Small pelvic arch changes are known to cause hip motion abnormalities (Perry, 1992).

Two patients had minimum flexion in the ankle joint in the injured side and could not perform ankle extension because of the severity of peroneal nerve palsy after injury. Ankle joint motion of these patients were evaluated separately from those who had ankle extension. Thus, the mean ankle extension in the patient group in the injured side did not significantly different from that of the control group. Ankle extension in the uninjured side of the patient group also did not differ from that of the control group.

GRF shows the muscular forces (quadriceps muscle and hamstrings) stabilising joints during loading response, and the second peak of the GRF shows the push of plantar flexor muscles during terminal stance. Thus, early rehabilitation measures for these patients can be used to strengthen the quadriceps muscle and hamstrings not only in the injured side, but also in the uninjured side, thus improving stabilisation of the knee joint during the loading response and knee flexion during the terminal stance. Increasing of the strength of the plantar flexor muscles would improve the push of the foot against the walking surface.

We evaluated patients in a significant range of time after polytrauma. Most clinical recovery outcomes of severe lower extremity trauma are attained after one year; therefore one year after trauma was considered to be within the period when the gait does not change significantly in the future (Castillo et al., 2011). Nevertheless, one patient had total hip replacement ten months after polytrauma (because of acetabular injury type C) and was included in gait analysis.

The age range of polytrauma and healthy control group individuals was considered to be appropriate to compare gait changes in our study, because many studies identify GD in the elderly after 65 years of age (Bleyenheuft and Detrembleur, 2012; Monaco and Micera, 2012; Jahn et al., 2010).

A limitation of our study was that it did not perform detailed analysis of the GD location and severity in comparison with lower extremity injury type, location, treatment methods and rehabilitation. Polytrauma patients have different injuries and there are only few patients with equal or similar injuries. In our study, a limited number of patients was involved, as we performed IGA only on consent of patients to arrive in the Rehabilitation Research Laboratory of Rīga Stradiņš University, National Rehabilitation Centre "Vaivari". Nevertheless, the IGA results for the uninjured lower extremity in the polytrauma patient group showed that compensatory changes are interdependent and changed spatio-temporal parameters and vertical load GRF occur in both the injured and uninjured side, regardless of injury type and location.

In conclusion, polytrauma patients had a decreased step length, cadence, maximum flexion in the knee joint, vertical load GRF and increased stance time, not only in the injured side, but also in the uninjured side. Further studies on a larger patients group will be needed to confirm this. 


\section{REFERENCES}

Ananjjeva, T., Pavāre, Z., Vētra, A., Lāriņš, V. (2010). Gait parameters of persons with total hip artroplasty. LASE (Latvian Academy of Sport Education) J. Sport Sci., 1, 42-48.

Archer, K. R., Castillo, R. C., MacKenzie, E. J., Bosse, M. J. (2006). Gait symmetry and walking speed analysis following lower-extremity trauma. Phys. Ther., 86, 1630-1640.

Bleyenheuft, C., Detrembleur C. (2012). Kinematic covariation in pediatric, adult and elderly subjects: Is gait control influenced by age? Clin. Biomech., 27, 568-572.

Castillo, R. C., MacKenzie, E. J., Bosse, M. J.; LEAP Study Group. (2011). Orthopaedic trauma clinical research: Is 2-year follow up necessary? Results from a longitudinal study of severe extremity trauma. J. Trauma, 71, 1726-1731.

Esquenazi, A., Talatu, M. (2000). Gait analysis: Technology and clinical applications. In: Grabois, M., Garrison, S. J., Hart, K. A., Lehmkuhl, L. D. (eds.). Physical Medicine and Rehabilitation: The complete approach (pp. 242-262). Cambrige, Malden: Blackwell Science.

Jahn, K., Zwergal, A., Schniepp, R. (2010). Gait disturbances in old age. Dtsch. Arztebl. Int., 107, 306-315.

Kubota, M., Uchida, K., Kokubo, Y., Shimada, S., Matsuo, H., Yayama, T., Miyazaki, T., Takeura, N., Yoshida, A., Baba, H. (2012). Changes in gait pattern and hip muscle strength after open reduction and internal fixation of acetabular fracture. Arch. Phys. Med. Rehabil., 93, 2015-2021.
Monaco, V., Micera, S. (2012). Age related neuromuscular adaption does not affect the mechanical efficiency of lower limbs walking. Gait Posture, 36, 350-355.

Pape, H. C., Zelle, B. A., Lohse, R., Hildebrand, F., Krettek, C., Panzica, M. Duhme, V., Sittaro, N.A. (2006). Evaluation and outcome of patients after polytrauma: Can patients be recruited for long term follow up? Injury, 37, 1197-1203.

Perry J. (1992). Gait Analysis: Normal and Pathological Function. New York: SLACK Incorporated. 551 pp. (at pp. 89-129).

Perry J., Burnfield, J. M. (2010). Gait Analysis: Normal and Pathological Function. 2nd ed. New York: SLACK Incorporated. 410 pp.

Pfeifer, R., Pape, H. C. (2011). Late outcome after severe fractures. In: Pape, H. C, Sanders, R., Borrelli, J. (eds.). The Poly-traumatized Patient with Fractures. A Multi-disciplinary Approach (pp. 349-355). London, New York: Springer.

Stevenson, M., Segui-Gomez, M., Lescohier, I., Di Scala, C., McDonald-Smith, G. (2001). An overview of the injury severity score and the new injury severity score. Inj. Prev., 7, 10-13.

Tran, T., Thordarson, D. (2002). Functional outcome of multiple injured patients with associated foot injury. Foot Ankle Int., 23, 340-343.

Trentz, O. L. (2007). Polytrauma: Pathophysiology priorities and management principles. In: Rüedi, T. P., Buckley, R. E., Moran, C. G. (eds.). AO Principles of Fracture Management. 2nd ed. (pp. 336-346). Switzerland: AO Publishing.

Received 24 June 2014

\section{GAITAS TRAUCĒJUMI PACIENTIEM PĒC PĀRCIESTAS POLITRAUMAS}

Gaitas novērtēšana pacientiem vidējā termiņā pēc politraumas dod iespēju plānot un veicināt šo pacientu atgriešanos darbā un iepriekšējo aktivitāšu veikšanu. Darba mērḳis bija novērtēt gaitu pacientiem ar apakšējo ekstremitāšu traumu sekām pēc pārciestas politraumas. Pētījumā iekḷauti 26 pacienti (16 sievietes, 10 vīrieši; vidējais vecums 38,6 gadi) 14-41 mēnesi pēc traumas. Šiem pacientiem veikta trīsdimensiju instrumentālā gaitas analīze (IGA) Rīgas Stradina universitātes Rehabilitoloǵijas pētnieciskajā laboratorijāan, Nacionālajā rehabilitācijas centrā „Vaivari”. Iegūtie dati salīdzināti ar kontroles grupas datiem. IGA ievainotajā pusē konstatēts samazināts soḷa garums, kadence, gūžas locītavas ekstensija, ceḷa locītavas maksimālā fleksija, atbalsta virsmas reakcijas spēks vertikāli, palielināts balsta fāzes laiks un iegurņa noliece uz priekšu; neievainotajā pusē konstatēts samazināts soḷa garums, kadence, ceḷa locītavas maksimālā fleksija, atbalsta virsmas reakcijas spēks vertikāli un palielināts balsta fāzes laiks $(p<0,05)$. Pētījumā iegūtie dati liecina par to, ka pacientiem pēc politraumas ar apakšējo ekstremitāšu traumu sekām ir gaitas traucējumi ne tikai ievainotajā pusē, bet arī neievainotajā pusēe, kurus var diagnosticēt, izmantojot IGA. 